\title{
TRANSNATIONAL CRIME AS A THREAT TO THE WORLD COMMUNITY
}

\section{Olga Kuznetsova $^{1 \star}$, Vera Shuniaeva ${ }^{2}$ and Maryus Murkshtis ${ }^{3}$}

\author{
${ }^{1}$ Ass. Prof. Olga Kuznetsova, RUDN University, Russia, kuznetsova-ola@rudn.ru \\ ${ }^{2}$ Ass. Prof. Vera Shuniaeva, Tambov State University named after Derzhavin, Russia, \\ Vera1705@mail.ru \\ ${ }^{3}$ Ass. Prof. Maryus Murkshtis, RUDN University, Russia, murkshtis-my@rudn.ru \\ ${ }^{*}$ Corresponding Author
}

\begin{abstract}
Transnational crime, unlimited by any barriers of a national or legal level, is currently acquiring the status of a supranational criminal phenomenon. Even though transnational crime harms the development of various countries, the number of which is continuously increasing, there is no clear and effective strategy to counter this type of crime. Transnational crime not only develops together with the world society but also accumulates the latest achievements of a technical and economic, political and other nature for its criminal purposes, which bring this type of crime to a new level. This level is often higher than the capabilities of law enforcement agencies of either a particular country or law enforcement syndicates in several countries. The study of transnational crime is given serious attention in the works of domestic and foreign authors; however, they lack a comprehensive approach that will help to generalize the most significant proposals and conclusions. Thus, it is necessary to study the best practices of various countries that successfully counter international organized crime.

This article explores not only the theoretical aspects of transnational crime, reflecting its main features, but also analyzes the reasons for its continual development from the current state of the world community, and also updates the most effective countermeasures. At the same time, the article addresses the problematic aspects of the fight against transnational crime.

The goal is achieved by solving the following tasks:

- Explore the main approaches to the study of transnational crime both in Russia and abroad;

- Identify the most common types of transnational crime that have a negative impact on a significant number of states;

- Study the development trends of transnational crime;

- Propose several measures aimed at countering transnational crime both in Russia and abroad.

The results of the study can be used in developing practical measures to counter transnational crime, in research activities to stimulate discussion on the most problematic issues of transnational crime, in teaching activities in the preparation of lecture and practical material on the subject "Criminology".
\end{abstract}

Keywords: transnational crime, internationalization, types of transnational crime, countering transnational crime.

\section{INTRODUCTION}

Even though transnational crime relatively recently acquired the official status, it has always existed. Of course, its scope and types corresponded to the capabilities of a particular historical period. Currently, transnational crime, unlimited by any barriers at a regional or legal level, is acquiring the status of a 
supranational criminal phenomenon. The study of transnational crime made it possible to identify not only the specific features inherent in this type of crime but also to compare its perception both in Russia and abroad.

There are both brief (Maksimov, S.V., 1995) and more detailed (Merkushin, V.V., 2003) definitions of the term "transnational crime". At the same time, the authors would like to note that the terms "transnational crime" and "transnational organized crime" are considered by us as identical concepts since the sign of organization is inalienable in transnational crime; therefore, it is also organized.

A.L. Repetskaya considers transnational crime as a "socially dangerous (criminally punishable) phenomenon, expressed in the functioning of criminal groups (communities) having a complex structure, manifesting themselves in the territory of several states, using favourable market conditions for obtaining illegal incomes and superprofits." (Repetskaya, A.L. 2010)

Professor I.M. Matskevich suggests to refer to "transnational organized crime" as " functioning of criminal groups of various degrees of organization, hierarchy and structuring, consisting of citizens of two or more states or stateless persons, is characterized by complex types of organized criminal activity carried out using transnational ties, including corrupt ties, and planning, executing or subsequent "committing criminal acts, in order to obtain economic benefits, as well as creating conditions that allow obtaining maximum profit, in the form of superprofits over the territory of two or more states." (Matskevich, I.M. (2017)

As one can see, despite the difference in formats, these definitions are similar and contain identical key features. Thus, the authors focus on the organization, structure, and therefore, hierarchy, on the quantitative composition (a group or community cannot consist of one person), on its qualitative characteristics that determine the supranational character, on its geography (commission of crimes or their preparation in different countries), for a selfish purpose with an end result in the form of profit.

Foreign authors adhere to the so-called "regional geographic approach" referring to transnational crime, for which the ethnic and geographical characteristics are specific features for a particular transnational criminal organization. (Emilio, C. Viano, José Magallanes, Laurent Bridel (2003). This approach is used by E. Savon and F. Williams. (The United Nations and Transnational Organized Crime. (1996). Susan Strange defines transnational crime as a threat to the entire global economy. (Susan Strange (1996). Many foreign authors also highlight such a significant sign of transnational crime, like money laundering or the use of other proceeds of crime. (The United Nations and Transnational Organized Crime. (1996)

The general understanding of the concept under consideration is recorded in Art. 3 of the UN Convention against Transnational Organized Crime, adopted in 2000, which states that "a crime is transnational in nature if:

a) It is committed in more than one state;

b) It is committed in one state, but a substantial part of its preparation, planning, management or control takes place in another state;

c) It is committed in one state, but with the participation of an organized criminal group that carries out criminal activity in more than one state; or

d) It is committed in one state, but its significant consequences take place in another state. (UN Convention against Transnational Organized Crime)

Thus, among Russian and foreign authors, there are conventional approaches to understanding transnational crime. Among the key features noted by domestic and foreign authors include organization, supranationality, ethnic - geographical features, as well as superprofits obtained through the laundering of the proceeds of crime.

Transnational crime not only develops in conjunction with world society but also accumulates the latest achievements of the technical and economic political and other nature for its criminal purposes, which brings this type of crime to a new level. There are currently more than 20 varieties of transnational crimes. We will name the most common ones that have a negative impact on a significant number of states.

First of all, the authors include any illegal treatment of narcotic drugs and psychotropic substances, as well as their components. This type of criminal activity is recognized as one of the most profitable, and its geography knows no boundaries. The global criminal community has divided this market: Afghanistan has become the largest producer of opioids, the United States - one of the leaders in the production of marijuana, Colombia specializes in cocaine, African countries and Asia are engaged in synthetic drugs.

Secondly, the illegal arms trade. This type of crime also carries the risk of a significant number of victims, as 
the weapons are sold to terrorist groups, separatist movements that purposefully use it against civilians. "As a result of such transactions, arms are transferred to countries subject to the UN Security Council embargo (such countries as Iraq, Libya, Somalia), or weapons are transferred to movements engaged in armed struggle against governments recognized by the international community (which are UN members and/or recognized by the vast majority of states of the world)." (Valeev, D.M. (2016))

Thirdly, trafficking persons with all other consequent crimes. According to the UN, from 2003 to 2016, about 225,000 victims turned to the UN for help, more than $70 \%$ of whom are women. (UN World Report on Trafficking in Human Beings). Trafficking persons is always accompanied by other crimes, for the sake of which the sale of a person is carried out. Most often it is sexual or other slavery, where girls and women, usually sold abroad, are forced to provide sexual services in brothels or privately. Human trafficking is often carried out with the aim of illegal removal of human organs, which are in high demand on the black market.

Fourth, computer (cyber) crime related to information and computer terrorism. Such types of crimes with the help of the Internet are committed instantly and can affect the interests of several states at once. With the development of technologies that allow computer systems to manage critical communications, the risk of targeted instalment of malicious programs by the transnational criminal community is created, which threatens not only the normal functioning of social infrastructure but also threatens nuclear and military facilities.

Fifth, we would like to mention terrorism as a specific type of transnational crime. For it there are no geographical or political boundaries. The authors argue with the opinion of D.M. Valeev, who believes that terrorism is not a form of transnational crime, considering that the victims are citizens of one country (Valeev, D.M. (2011). The modern history of terrorist acts in France, in Germany, in Russia proves that the victims are representatives of different states. At the same time, despite the fact that terrorism is an independent type of transnational crime, it can be considered as a symbiosis of certain crimes, such as arms, drugs, human trafficking, and computer terrorism.

A variety of types of crimes described above is united by such a system-forming feature as transnationality.

\section{METHODOLOGY}

It is evident that in Russia and abroad, serious attention is being paid to the study of transnational crime, which is causing serious damage to the entire world community. However, the ever-changing transnational crime requires new approaches to its study. In this connection, within the framework of this article, we have set the task of studying the main trends in the study of transnational crime in Russia and abroad, as well as its types, with the aim of proposing certain measures aimed at countering transnational crime, both in Russia and abroad.

The methodological basis of the research is constituted by such general scientific methods as the dialectical, systematic method of research, analysis, synthesis, induction, deduction, analogy, and alike, as well as such private scientific methods as historical-legal, comparative-legal, formal-legal, structural-functional, statistical. In work on the topic, the authors relied on the results of research by Russian and foreign jurists, sociologists in the field under consideration.

\section{RESULTS}

\subsection{Reasons for the Progressive Development of Transnational Crime}

Traditionally, factors contributing to the development of crime are divided into internal and external.

The internal factors of transnational crime include:

- Economic processes that either impede legal business, which brings super profits, or the so-called economic liberalism, which reduces and sometimes evens out the role of the state in regulating the economic sector;

- Gaps in domestic legislation leading to the absence of legislative barriers to the creation and operation of organized criminal groups, whose interests extend beyond the borders of one state;

- The insignificant potential of law enforcement and judicial bodies, including corruption. A high level of transnational crime is often higher than the capabilities of law enforcement agencies, both individual countries and law enforcement syndicates in several countries;

- The cohesion of a significant number of people with a common idea (religious, national, political or other types), a movement that is carried out not in a peaceful, constructive way, but a criminal; 
- And others.

As the external causes of the development of transnational crime can be considered:

- Wars of any format, including cold ones. They contribute to the illegal movement of weapons, human trafficking and several other types of transnational crimes;

- The collapse of states, such as the USSR, gave rise to ethnic conflicts that led to a surge in the terrorist movement;

- The creation of customs unions and visa-free regimes facilitated the transnational criminal groups to commit any crime in the field of drug trafficking;

- Migration growth creates both a talent pool for transnational criminal communities, and contributes to the creation of rival groups, enriched by the commission of various types of transnational crimes;

- Globalization, with its capabilities is also used by criminal structures: the absence of international barriers to trade allows criminal capitals to move almost unhindered, thereby washing them.

Thus, the external and internal causes of the development of transnational crime pose a threat to the security of the world community.

\subsection{Domestic and Foreign Experience in Combating Transnational Crime}

The effectiveness of measures to counter transnational crime largely depends on a shared understanding of global problems and the concentration of efforts to implement these measures. The leading role in regulating the processes under consideration is played by international organizations, among which the United Nations has a special position.

The UN initiated the development of unified, universal documents aimed at countering transnational crime: the Council of Europe also supports such initiatives. The most significant documents in this area were: UN Convention against Transnational Organized Crime (2000); United Nations Convention against Illicit Traffic in Narcotic Drugs and Psychotropic Substances, 1988; UN Slavery Convention (1926); un convention against trafficking in persons and the exploitation of the prostitution of others (1949); Protocol against the Illicit Manufacturing of and Trafficking in Firearms, Their Parts and Components and Ammunition, supplementing the United Nations Convention against Transnational Organized Crime (2001); Council of Europe Convention on cybercrime (2001); Additional Protocol to the Convention on Human Rights and Biomedicine regarding the transplantation of organs and tissues of human origin (2002) and several other documents.

The indicated normative acts provide for various forms of interaction both at the level of the state as a whole and at the level of its individual bodies. However, problems arise if a number of states refuse to ratify these acts, which lead to difficulties in cooperation.

Particular attention should be paid to extradition, which should confirm the principle of the inevitability of responsibility; otherwise, impunity of representatives of transnational criminal groups will contribute to the growth of their crimes.

One of the priority measures to counter transnational crime is the stabilization of the economy in the world community, which minimizes the role of the shadow economy and its manifestation.

The fight against large criminal syndicates and other criminal communities with a view to their separation or elimination is of grave importance.

An important aspect should be the control of state borders. Regardless of the various kinds of unions, borders should present a real barrier to the commission of all kinds of transnational crimes, taking into account modern technologies and technical capabilities of transnational crime.

It is necessary to eliminate the causes that contribute to intrastate and interethnic conflicts, as well as minimize external pressure on intrastate development.

The basis of all countermeasures should be in compliance with such relevant principles of crime prevention as timeliness and effectiveness.

\section{CONCLUSIONS}

Thus, it is necessary to study the best practices of various countries that successfully counter international organized crime. Mutual understanding of the problems of transnational crime will allow carrying a productive dialogue among countries aimed at developing a unified strategy to combat transnational crime. 


\section{ACKNOWLEDGEMENT}

This article has been prepared in the framework of RUDN University participation of Russia-wide 5-100 program.

\section{REFERENCE LIST}

Maksimov, S.V. (1995) Brief criminological dictionary. Moscow. Yurist, 32 pages.

Merkushin, V.V. (2003) The fight against transnational organized crime. Minsk. pp. 23-24.

Repetskaya, A.L. (2010) Organized crime. Shadow economy. The criminal market of Russia. Moscow. Yurlitinform, $192 \mathrm{p}$.

Matskevich, I.M. (2017) Transnational organized crime: concept and signs. Bulletin of Moscow University. Series Law. No 4., p.76.

Emilio, C. Viano, José Magallanes, Laurent Bridel (2003) Transnational Organized Crime. Myth, Power, and Profit. Carolina academic press. Durham, North Carolina.

The United Nations and Transnational Organized Crime. (1996) By Philip Williams, Phil Williams (Editor), Ernesto U. Savona (Editor). 208 pp.

Susan Strange (1996) The Retreat of the State: The Diffusion of Power in the World Economy. Cambridge University Press. 239pp.

UN Convention against Transnational Organized Crime of November 15, 2000, https://www.un.org/ru/documents/decl_conv/conventions/orgcrime.shtml (accessed December 3, 2019)

Valeev, D.M. (2016) International legal framework for cooperation against transnational organized crime. Dissertation for the degree of PhD. Kazan. pp. 62-63.

UN World Report on Trafficking in Human Beings https://www.unodc.org/unodc/en/data-andanalysis/glotip.html (address of December 3, 2019)

Valeev, D.M. (2011) Transnational organized crime: the concept and its essence. Gaps in Russian law. No 1. p.159. 